\title{
Nutrition in the expression of reproductive potential
}

\author{
J.J. Robinson, T.G. McEvoy and C.J. Ashworth
}

Scottish Agricultural College, Animal Biology Division

Craibstone Estate, Bucksburn, Aberdeen, AB219YA, UK

\begin{abstract}
Until recently, studies of the influence of nutrition on reproductive events such as the timing of puberty, the occurrence of ovulation in single-ovulating species and the actual numbers of ova shed in 'multiple ovulators' such as the pig and sheep dominated nutritional aspects of reproduction research. The emphasis is now switching to studies of the impact of nutrition during key periods of development in utero on subsequent production potential including reproduction. Already there is evidence that nutrition during early embryonic development can affect the foetal growth trajectories and size at birth. There are also data to indicate that nutrition during oogenesis not only affects ovulation rate but also embryo development and possibly the nature of the subsequent foetal growth and development processes. Coming at a time when functional genomics is capturing the attention of nutritionists, these observations are providing a unique and valuable opportunity to carry out research linking whole animal production responses with the underlying molecular and cellular biology. The present review describes a range of examples of the effects of dietary nutrients on gene expression during key periods of embryonic and foetal development. In doing so it illustrates the impact that nutrition in utero could have on improving animal production through its contribution to functional genomics.
\end{abstract}

KEY WORDS: nutrition, gene expression, reproduction

\section{INTRODUCTION}

Respect for each other's research contributions in defining the energy requirements of farm animals during the 1960's resulted in the establishment of a close friendship between Professor Jan Kielanowski, Director of the Institute of Animal Physiology and Nutrition at Jabłonna, and Sir Kenneth Blaxter, Director of the Rowett Research Institute in Aberdeen. This in turn led to a series of scientific interchanges between the two Institutes. During one of these interchanges, long 
before oilseed rape became a major crop in Britain, I (JJR) spent the summer of 1975 in Jabłonna working with Jan Kowalczyk on the nutritive value of rapeseed meal. Later that year Jan came to Aberdeen where, along with Robert Ørskov, Colin Stewart and myself, he investigated the effect of lipid supplementation on voluntary food intake and rumen metabolism. These are just a couple of examples from that time of collaborative investigations by researchers from each of the Institutes with aspirations to improve the nutrition of farm livestock. We still share those aspirations and, within the context of this Symposium on 'New Trends in Animal Nutrition', I am honoured to have been invited to contribute this review on nutrition and reproduction.

Coming at a time when nutritionists are preparing to take on the challenge presented by functional genomics, studies of the role of nutrition in the expression of reproductive potential are particularly relevant. They provide new opportunities for metabolic investigations linking observations in the whole animal with the underlying molecular and cellular biology (Young and Ajami, 2001). In the case of the reproducing animal this link has additional importance in that nutrients are not just involved in cell proliferation and tissue growth but also in the exquisitely sensitive processes of cell and tissue differentiation that ensure normality of form and function in the neonate. The actions of nutrients are both direct, as in the provision of essential substrates, and indirect through their ability to alter the expression of the numerous maternal and foetal endocrine mechanisms that operate during reproduction (Dauncey et al., 2001). These influence the availability and utilization of nutrients at the cell and tissue level.

Specific nutrients exert their effects via alterations in gene expression at stages which range from transcription of the genetic sequence to the production of a functional protein (Taylor and Brameld, 1999). Nutritional and metabolic research at this level is demonstrating that diet can regulate mRNA translation and stability via the effects of specific nutrients on the control of regulatory signals in untranslated regions of the mRNA (Hesketh et al., 1998). The result is that measurements of the abundance of mRNA are inadequate indices of nutritionally-mediated alterations in gene expression and thus accompanying quantitative measurements of the functional protein product are required. Post-transcriptional nutritional regulation of gene expression in the untranslated mRNA regions can also influence nutrient requirements and the delivery of specific nutrients not just to the correct cell but also to the correct compartment (cytoplasmic domain or organelle) within the cell (Hesketh et al., 1998).

These brief comments on nutrition and gene expression provide a flavour of the likely research emphasis as nutritional science now enters the post-genomic era. The purpose of this review is not to delve deeper; rather it is to use a number of examples, ranging from whole animal observations to those of alterations in gene expression, in order to highlight some of the more intriguing and challenging as- 
pects of the nutritional control of reproduction. The approach is deliberately selective and certainly not exhaustive. It docs however attempt to provide examples that span the enormous diversity of physiological states and requirements for nutrients that transform an oocyte into a viable neonate. It also embraces the concept that alterations in nutrient supply during critical stages of development (e.g., oocyte, embryo, foetus) can impart a legacy of changes that affect the viability of the newborn and its subsequent performance.

\section{NUTRITIONAL LEGACIES}

The nature of the reproductive process is such that there are many opportunities for specific nutrients to impart their effects at the cell, molecule and gene level. Often these effects are not immediately obvious in the whole animal or indeed at organ and tissue level. They may however have profound and clearly visible downstream programming effects on the final expression of the reproductive process in terms of the numbers of newbom produced, their viability and normality. When, on the basis of whole animal observations, any of these outcomes are unsatisfactory the quest begins to find out where, when and how the adverse effect(s) occurred. Increasingly research generated by whole animal observations is leading to investigations at the cell, molecule and gene level. Selected examples of nutritional legacies on key reproductive measures such as ovulation, embryo survival, the growth and development of the foetus and the vitality and viability of the neonate illustrate this point; they also provide a framework for further research.

\section{Ovulation}

The nutritional control of ovulation in the ewe provides an excellent example of the value of whole animal observations in guiding the more fundamental sciences into relevant areas of biology. Thus, the use by Gunn et al. (1995) of observations on lamb production by Scottish Blackface ewes, which revealed that foetal undernutrition could lead to a significant reduction in the number of lambs produced (litter size) during adulthood, opened up investigations into the causal mechanisms. Results from these investigations are now indicating that the effects are probably programmed during early foetal life (prior to day 50) and are characterised by a delay in the normal developmental process of oogonial degradation in the foetal ovary and an associated postponement in the arrest of foetal ovarian meiotic activity (Borwick et al., 1997). The nutritional effect on the foetal ovary appcars to be direct and not via an alteration in gonadotrophin gene expression in the foetal pituitary gland (Da Silva et al., 2000). Furthermore it occurs in the absence of an effect on foetal weight (Borwick et al., 1997). 
The above example of the power of whole animal observations in directing fundamental science into unravelling some of the underlying mechanisms controlling ovulation rate is by no means unique. Careful multi-generational recording, firstly of litter size in sheep and then of ovulation rate in their progeny, enabled George Davis at the Invermay Agricultural Centre in New Zealand to identify a single gene for enhanced ovulation rate located on the X-chromosome of some animals of the Romney breed (Davis, 1994). Subsequent application of molecular techniques by Galloway et al. (2001) has demonstrated that the increase in ovulation rate is caused by a mutation in an oocyte-derived growth factor gene (BMP/5) which is a member of the transforming growth factor $\beta(T G F \beta)$ superfamily. It is not yet known whether the magnitude of expression of the gene is influenced by nutrition. There is evidence however that another prolific sheep genotype (the Booroola Merino) which also exhibits a mutation of a gene $(B M P R-l B)$ from the TGF $\beta$ pathway (Wilson et al., 2001) is affected, in terms of its expression, by nutrition (Landau et al., 1995). In the Landau et al., study, carriers of the gene responded to $100 \mathrm{~g} /$ head/day of supplementary rumen undegraded starch in the 3 weeks before mating with a mean ovulation rate ( \pm s.e.m.) of $3.29 \pm 0.27$ compared with 2.46 \pm 0.31 for unsupplemented carriers of the gene. Corresponding values for non-carriers were $1.44 \pm 0.25$ and $1.36 \pm 0.34$. By again adopting a multi-generational approach, this time involving observations of ovulation rates over four generations, Davis et al. (2001) have identified an imprinted gene $\left(\mathrm{FeCX} 2^{W}\right)$ for enhanced ovulation rate in some ewes of the Coopworth breed.

In all of these studies the importance of gene identification lies in its value in marker-assisted genetic selection programmes; also, from the nutritionist's point of view, there is the possibility that the biochemical pathways controlled by the gene may be responsive to specific dietary nutrients. Molecular studies therefore provide the necessary scientific information for identifying, at a young age, animals carrying the gene and for ensuring that they receive the nutritional inputs and management that are required to optimise their reproductive performance.

Of course, before genes and metabolic or other pathways for the control of ovulation were being investigated at this level, it was well recognised that the ewe's body condition at mating (static effect) and her pre-mating change in condition (dynamic effect) influence ovulation rate. There even was the suggestion that plane of nutrition approximately 6 months prior to ovulation could affect ovulation rate, as this coincides with the time that ovarian follicles exit the primordial pool and become committed to growth. It is also the time when ewes are passing through peak lactation and invariably are drawing on body reserves to meet dietary deficits. In this regard the demonstration by Nottle et al. (1997) that the adverse effect of an energy deficit at this time on subsequent ovulation rate can be prevented by a period of high-plane feeding prior to ovulation (flushing) is particularly important. Observations of this nature, coupled with improved understanding of the molecu- 
lar mechanisms controlling follicle growth and development (Webb et al., 1999), provide new opportunities for research into the development of feeding strategies closely aligned with the animal's nutrient requirements during critical phases of ovarian folliculogenesis.

\section{The embryo}

The exploration of nutritional and other environmental effects on gene expression in the embryo is a rapidly expanding area of research interest. The approach involves embryos cultured in vitro as well as those in their natural in vivo environment. Combined results are demonstrating that the environment of the early embryo (up to the expanded blastocyst stage; days 6 to 7 post-fertilization in sheep and cattle) can have major effects on the expression of genes that influence its viability, the subsequent growth and development of the foetus and the vitality and health of the newborn. The in vitro dimension to the research arises from the potential benefits to quality beef production from the dairy herd that could come from replacing artificial insemination of dairy cows with non-surgical transfer of in vitro produced embryos from beef breeds (Gordon, 1989). In practice, due to what is now widely known as the large offspring syndrome, LOS (Young et al., 1998) that potential has not yet been achieved. Rather what has emerged from the work is the finding that the in vitro culture of ruminant embryos (cattle and sheep) from the zygote to blastocyst stage followed by transfer to synchronous recipients leads to an unacceptably high incidence of foetal overgrowth and associated increases in the allometric growth coefficients for key foetal organs and tissues, most notably heart, kidneys and skeletal muscles (Sinclair et al., 1999). Although disappointing from the practical point of view, the findings are bringing a new dimension to our understanding of the endocrine control of foetal growth and development and of the dependence of the foetal growth processes on the environment of the early cleavage-stage embryo. For example large foetuses arising from in vitro embryo culture have higher circulating concentrations of insulin-like growth factor binding protein 2 (IGFBP2) and enhanced hepatic IGFBP2 gene expression (Young et al., 1999). Their organs and tissues (liver, kidneys, heart and skeletal muscles) exhibit reduced expression of the imprinted insulin-like growth factor 2 receptor gene $(I G F 2 R)$ and this is associated with an epigenetic loss of DNA methylation (Young et al., 2001).

Another example of the sensitivity of foetal development to the environment of the early embryo is the observation by Maxfield et al. (1998) that a temporary 3-day exposure of day 3 sheep embryos to an advanced (day 6) uterine environment increased muscle fibre number and the ratio of secondary to primary fibres in the foetus; it also altered the temporal expression of the myogenic gene, myf 5 , implying that this gene is involved in prolongation of foetal myoblast hyperplasia. 
In attempting to link in vivo and in vitro observations we have shown that elevation of the ammonia concentrations $(\sim 150 \mu \mathrm{mol} / \mathrm{l})$ in the environment to which sheep embryos are exposed either in vivo by adding excess rumen degradable protein (RDP) to the diet (McEvoy et al., 1997) or in vitro through the addition of serum to the culture medium (Negrin-Pereira et al., 1997) is accompanied by up-regulation of embryo metabolism, and enhanced foetal growth. Indeed there is now evidence that dietary effects may be programmed before fertilization; for example, Sinclair et al. (2000) found that excess RDP given to donor heifers increased de novo protein synthesis in blastocysts produced from their follicle-aspirated oocytes. In the case of superovulated ruminant animals it is now well recognised that unlike their spontaneously-ovulating counterparts there is a detrimental effect of pre-ovulatory high-plane feeding on embryo quality. The detrimental effects are accentuated by concentrate diets that are rapidly fermented in the rumen with the effects on the embryo manifest as greater reliance on pyruvate and enhanced expression of mRNA for superoxide dismutase $(\mathrm{Cu} / \mathrm{Zn}-\mathrm{SOD})$ which is indicative of cellular stress (Wrenzycki et al., 2000). In the context of embryo stress, alterations in the expression of growth arrest genes (gas 5, CHOP-10 or GADD 153) offer the prospect of using stress-responsive genes as embryonic markers of current events and as possible predictors of subsequently deviant shifts in foetal growth and development arising from sub-optimal embryo culture (Fontanier-Razzaq et al., 2001) or, eventually, maternal nutrition (Rees et al., 1998).

\section{The foetus}

Research into nutritional effects on foetal growth has been given a new direction with the observations that human cardiovascular disease and non-insulin diabetes in adult life have their origins in the adaptations that the foetus makes to alterations in maternal nutrition (Barker, 1994). As a result greater emphasis is now being placed on the effects of nutrition on foetal organogenesis, the foetal endocrine axis and the expression of genes in target tissues. The nutritional effects on the foetal ovary referred to earlier are one example relevant to animal production; there are others. For example Dwycr et al. (1994) noted that a doubling of the current recommended level of feeding of sows between days 25 and 50 of gestation (coincident with the proliferation of secondary myoblasts) increased the production of secondary myofibres in foetal muscles and enhanced post-natal growth rate and feed conversion efficiency. From their recent observations on foetal sheep Buttery et al. (2000) speculated that such an effect could be mediated via a dietaryinduced change in foetal hepatic IGF-I expression and a corresponding temporal shift in skeletal muscle IGF-II expression. Since modern pig genotypes are the result of intense selection for high rates of growth of lean tissue it is tempting to 
speculate that their enhanced genetic potential for this trait may place a new set of standards on their in utero demands for specific nutrients during foetal myogenesis. Thus, it may not be merely coincidental that adult wool production in the Merino, a trait that has likewise been highly selected for, is also responsive to in utero nutrition during the last trimester of pregnancy when the foetus acquires its secondary wool follicles (Kelly et al., 1996). It is perhaps also worth noting that the nutritional effects on the foetal sheep ovary referred to earlier were observed in the Scottish Blackface, a breed whose adult ovulation rate is highly responsive to its contemporaneous nutrition.

Not all in utero nutritional effects are clearly understood in terms of their mode of action or indeed the precise target tissue that is affected. For example subclinical cobalt deficiency during early pregnancy in ewes has adverse effects on the vigour of lambs at birth (Fisher and MacPherson, 1991). Although birthweights are not affected, lambs from deficient ewes are slow to stand and suck. As a result their acquisition of passive immunity is compromised; so too is their chance of survival. Interestingly correction of the deficiency during late pregnancy does not alleviate the problem, implying that the adverse effects are programmed at an earlier but critical period of development. Whether this programming occurs during foetal organogenesis or at an earlier embryonic stage is not known. Although the causal mechanisms have not been identified cobalt deficiency leads to an increase in homocysteine production (Rosenquist and Finnell, 2001) which in turn is known to alter methylation of DNA (Rees et al., 2000) thus providing a plausible explanation for its effect at the gene level. Numerous other trace elements and vitamins also play important roles in embryonic and foetal development (Ashworth and Antipatis, 2001). Their effects on cell proliferation and differentiation in the foetus are mediated via alterations in hormone concentrations, the expression of growth factors and gene transcription. Often, excesses as well as deficiencies are detrimental to normal development (Ross et al., 2000), with feed and forage toxicants also having an impact (McEvoy et al., 2001); hence the importance of studies that link diet to expression, by the embryo and foetus, of key developmental genes (Antipatis et al., 1998; Rees et al., 1999).

As well as acknowledging the essential roles of micronutrients in enzymes and in signal transduction pathways that regulate pre-natal development, Ashworth and Antipatis (2001) developed the argument that, through their effect on antioxidant status, micronutrient excesses and deficiencies may programme in utero effects that have long-term consequences.

Historically, many of the adverse effects of micronutrients on foetal development and neonatal viability have been observed following improvements in the general nutrition of the animal in the absence of a corresponding improvement in the supply of a specific micronutrient. There is now evidence that improvements in 
nutrition prevent maternal tissue catabolism and the generalised release of nutrients that would otherwise have alleviated the specific nutrient deficiency (Robinson et al., 1999; Ashworth and Antipatis, 2001).

With regard to the effects of specific nutrients which operate via the foetal endocrine system to control development and competence at birth, iodine and selcnium are important examples. Thyroxine (T4) and tri-iodothyronine (T3), which are iodine-dependent hormones, play important roles in cell and tissue differentiation (Fowden, 1995). They are also involved in lung maturation and the development of brown adipose tissue, both of which are important in neonatal thermogenesis (Symonds, 1995) and therefore survival at birth. It is now known that the enzyme (iodothyronine 5-deiodinase) which converts $\mathrm{T} 4$ to the active thyroid hormone T3 in extra-thryoidal tissue including brown adipose tissue is selenium-dependent (Arthur, 1999). It is thus highly likely that inadequate selenium intake during late pregnancy will accentuate the effects of iodine deficiency on the expression of neonatal vigour. In utero nutrient supply also affects the expression of thyroid hormone receptors in key foetal tissues. For example, in their review of the implications for foetal development of nutrition-hormone receptor-gene interactions, Dauncey et al. (2001) draw attention to their observations for the foetal pig, which illustrate that intrauterine growth retardation is associated with a doubling in the expression of the TR $\alpha 2$ isoform of the thyroid hormone receptor in skeletal muscle. These authors argue that this up-regulation of TR $\alpha 2$ decreases transcription of target genes leading to impaired expression of muscle form and function which, presumably, has implications for post-natal lean tissue growth.

The glucocorticoids, which are also influenced in terms of their circulating concentrations in the foetus by maternal nutrition, play a central role in foetal development through their involvement in the switch from cell proliferation to differentiation (Fowden et al., 1998). The effect of nutrition, specifically in regulating the expression of glucocorticoid receptors in foetal tissues is just beginning to attract research interest. Initial observations (Dauncey et al., 2001) suggest that receptor studies will provide important information on in utero nutrient requirements for optimal neonatal survival and post-natal skeletal muscle growth.

\section{DAIRY COW FERTILITY - A CHALLENGE FOR RESEARCH}

Over the last 25 years genetic selection for increased milk production in the UK dairy herd, while highly effective in achieving its specific goal, has been accompanied by a steady decline of $1 \%$ per year in calving to first insemination (Royal et al., 2000). Contrary to what might be expected from the increased mobilization of body reserves and therefore larger negative energy balance associated with enhanced milk yields, there has been no concomitant delay in the time of first ovula- 
tion post calving; rather the most notable change over the last 25 years of genetic selection has been a significant increase in the proportion of cows that exhibit delayed luteolysis following either their first or subsequent ovulations post-calving (Lamming and Royal, 2001). Increased embryo mortality may be a factor contributing to the reduced calving rate. Indeed the results of a recent study (Snijders et al., 2000) indicate that oocytes from cows selected for high milk yield have a lower capacity to produce blastocyst-stage embryos in vitro than those from their 'moderate yielding' counterparts. It is not known whether this reduced capacity arises from an inherent reduction in oocyte quality that is linked to genetic selection for milk yield or is the result of an associated 'reproductively detrimental' shift in pre-ovulatory nutrition. It may even be as a result of inadequate nutrition for the development of the foetal ovary, as noted in the foetal sheep studies of Borwick et al. (1997). In pursuing a pre-ovulatory nutritional explanation for the reduced embryo survival, Butler (2001) presented data to suggest that high blood urea concentrations, which often occur in high-yielding dairy cows, combine with the high genetic merit cow's sub-optimal early luteal progesterone concentrations to reduce embryo survival.

Although much still remains to be done before the relentless decline in dairy cow fertility can be reversed there is cause for optimism. Largely as a result of improved understanding of the molecular mechanisms involved in the maintenance of pregnancy through activation of the JAK-STAT pathway (Thatcher et al., 2001) in response to embryonic interferon tau $\left(\mathrm{IFN}_{\tau}\right)$, practical methods are emerging for enhancing embryo survival. Of these the most relevant is the ability of specific fatty acids such as eicosapentaenoic acid (EPA; 20:5n-3) and docosahexaenoic acid (DHA; 22:6n-3), fish oil being a rich source, to suppress the endometrial $\mathrm{PGF}_{2 \alpha}$ challenge faced by the trophoblastic antiluteolysin, IFN $\mathrm{N}_{\tau}$, in early pregnancy.

\section{CONCLUSIONS}

In this review, many of the examples of nutritional effects on gene expression during critical periods of embryonic and foetal development and of their subsequent influence on production suggest that we are still a long way from devising life-time feeding strategies that allow full expression of the genetic potential of our farmed species. The examples also prompt the question: are animals that are selected for extreme traits such as enhanced ovulation rates, increased muscle tissue growth, high wool production or excessive milk yields more susceptible to deviant or inadequate in utero nutrition than their less productive counterparts?

Taking nutritional research into the field of functional genomics promises to reveal new opportunities for improving reproductive efficiency by better-informed optimisation of nutrition. Central to this approach will be the acquisition of infor- 
mation on the effects of specific dietary nutrients on the expression of genes and metabolic pathways in the oocyte, embryo and foetus that play important roles in determining the post-natal manifestation of production traits.

\section{ACKNOWLEDGEMENTS}

Original work from our laboratory presented in this review was funded by the Scottish Executive Rural Affairs Department and by the Ministry of Agriculture Fisheries and Food.

\section{REFERENCES}

Antipatis C., Ashworth C.J., Grant G., Lea R.G., Hay S.M., Rees W.D., 1998. Effects of maternal vitamin A status on fetal heart and lung: changes in expression of key developmental genes. Amer. J. Physiol. 275, L1184-L1191

Arthur J.R., 1999. Functional indicators of iodine and selenium status. Proc. Nutr. Soc. 58, 507-512

Ashworth C.J., Antipatis C., 2001. Micronutrient programming of development throughout gestation. Reproduction (in press)

Barker D.J.P., 1994. Mothers, babies and disease in later life. BMJ Publishing Group, London

Borwick S.C., Rhind, S.M., McMillan S.R., Racey P.A., 1997. Effect of undernutrition of ewes from the time of mating on fetal ovarian development in mid-gestation. Reprod. Fert. Develop. 9, $711-715$

Butler W.R., 2001. Nutritional effects on resumption of ovarian cyclicity and conception rate in postpartum dairy cows: In: M.G. Diskin (Editor). Fertility in the High-Producing Dairy Cow. Occasional Publication No. 26, British Society of Animal Science, Edinburgh, pp. 133-145

Buttery P.J., Bramfeld J.M., Dawson J.M., 2000. Control and manipulation of hyperplasia and hypertrophy in muscle tissue. In: P.B. Cronjé (Editor). Ruminant Physiology: Digestion, Mctabolism, Growth and Reproduction. CAB International, Wallingford (UK), pp. 237-254

Da Silva P.. Aitken R.P., Rhind S.M., Wallace J.M., 2000. The effect of nutritionally-mediated placental growth restriction on fetal pituitary gonadotrophin gene expression and gonadal morphology at Day 104 of gestation. J. Reprod. Fertil., Abstr. Ser. 25, 94

Dauncey M.J., White P., Burton K.A., Katsumata M., 2001. Nutrition-hormone receptor-gene interactions: implications for development and disease. Proc. Nutr. Soc. 60, 63-72

Davis G., 1994. Encounters with the Inverdale Gene, 1968-1991. In: G.H. Davis (Editor). 'Lab Coats to Gumboots'. New Zealand Society of Animal Production, Occasional Publication No. 13, pp. $29-53$

Davis G.H., Dodds K.G., Wheeler R., Jay N.P., 200I. Evidence that an imprinted gene on the X chromosome increases ovulation rate in sheep. Biol. Reprod. 64, 216-221

Dwyer C.M., Strickland N.C., Fletcher J.M., 1994. The influence of maternal nutrition on muscle fiber number development in the porcine fetus and on subsequent postnatal growth. J. Anim. Sci. 72, $911-917$

Fisher C.E.J., MacPherson A., 1991. Effect of cobalt deficiency in the pregnant cwe on reproductive performance and lamb viability. Res. Vet. Sci. 50, 319-327 
Fontanier-Razzaq N., McEvoy T.G., Robinson J.J., Rees W.D., 2001. DNA damaging agents increase gadd153 (CHOP-10) messenger RNA levels in bovine preimplantation embryos cultured in vitro. Biol. Reprod. 64, 1386-1391

Fowden A.L., 1995. Endocrine regulation of fetal growth. Reprod. Fertil. Develop. 7, 351-363

Fowden A.L., Li J., Forbead A.J., 1998. Glucocorticoids and the preparation for life after birth: are there long-term consequences of the life insurance? Proc. Nutr. Soc. 57, 113-122

Galloway S.M., McNatty K.P., Cambridge L.M., Laitinen M.P.E., Juengel J.L., Jokiranta T.S., McLaren R.J., Luiro K., Dodds K.G., Montgomery G.W., Beattie A.E., Davis G.H., Ritvos O., 2000. Mutations in an oocyte-derived growth factor gene (BMP/5) cause increased ovulation rate and infertility in a dosage-sensitive manner. Nat. Genet. 25, 279-283

Gordon 1., 1989. Large-scalc production of cattle embryos by in vitro culture methods. AgBiotech News Inf. 1 (3), 345-348

Gunn R.G., Sim D.A., Hunter E.A., 1995. Effects of nutrition in utero and in early life on the subsequent lifetime reproductive performance of Scottish Blackface ewes in two management systems. Anim. Sci. 60, 223-230

Hesketh J.E., Vasconcelos M.H., Bermano G., 1998. Regulatory signals in messenger RNA: determinants of nutrient-gene interaction and metabolic compartmentation. Brit. J. Nutr. 80, 307-321

Kelly R.W., Macleod I., Hynd P,, Greeff J., 1996. Nutrition during fetal life alters annual wool production and quality in young Merino sheep. Aust. J. Exp. Agr. 36, 259-267

Lamming G.E., Royal M.D., 2001. Ovarian hormone patterns and sub fertility in dairy cows. In: M.G. Diskin (Editor). Fertility in the High-Producing Dairy Cow. Occasional Publication No. 26, British Society of Animal Science, Edinburgh, pp. 105-118

Landau S., Bor A., Leibovich H., Zoref Z., Nitzan Z., Madar Z., 1995. The effect of ruminal starch degradability in the dict of Booroola crossbred ewes on induced ovulation rate and prolificacy. Anim. Reprod. Sci. 38, 97-108

Maxficld E.K., Sinclair K.D., Dunne L.D., Broadbent P.J., Robinson J.J., Stewart E., Kylc D.G., Maltin C.A., 1998. Temporary exposure of ovine embryos to an advanced uterine environment does not affect fetal weight but alters fetal muscle development. Biol. Reprod. 59, 321-325

McEvoy T.G., Robinson J.J., Aitken R.P., Findlay P.A., Robertson I.S., 1997. Dietary excesses of urea influence the viability and metabolism of preimplantation sheep cmbryos and may affect fetal growth among survivors. Anim. Reprod. Sci. 47, 71-90

McEvoy T.G., Robinson J.J., Ashworth C.J., Rooke J.A., Sinclair, K.D., 2001. Feed and forage toxicants affecting embryo survival and fetal development. Theriogenology 55, 113-129

Negrin Pereira N., McEvoy T.G., Staines M.E., Broadbent P.J., Mackie M., Ranilla M., Robinson J.J., 1997. Effect of exposure to two different culture systems on the development and metabolism of in vivo derived sheep zygotes. Theriogenology 47,377

Nottle M.B., Klcemann D.O., Seamark, R.F., 1997. Effect of previous undernutrition on the ovulation rate of Merino ewes supplemented with lupin grain. Anim. Reprod. Sci. 49, 29-36

Recs W.D., Harries D.N., Fleming J.V., 1998. Partial sequences of two genes regulated by amino acid supply identified by the use of RNA fingerprinting by arbitrarily primed PCR. J. Nutr. Biochem. 9, 136-141

Rees W.D., Hay S.M., Brown D.S., Antipatis C., Palmer R.M., 2000. Matemal protein deficiency causes hypermethylation of DNA in the livers of rat fetuses. J. Nutr. 130, 1821-1826

Rees W.D., Hay S.M., Fontanier-Razzaq N.C., Antipatis C., Harries D.N., 1999. Expression of the growth arrest genes (GAS and GADD) changes during organogenesis in the rat foetus. J. Nutr. $129,1532-1536$

Robinson J.J., Sinclair K.D., McEvoy T.G., 1999. Nutritional effects on foetal growth. Anim. Sci. $68,315-331$ 
Rosenquist T.H., Finnell R.H., 2001. Genes, folate and homocysteine in embryonic development. Proc. Nutr. Soc. 60, 53-61

Ross S.A., McCaffery P.J., Drager U.C., De Luca L.M., 2000. Retinoids in embryonal development. Physiol. Rev. 80, 1021-1054

Royal M.D., Darwash A.O., Flint A.P.F., Webb R., Woolliams J.A., Lamming G.E., 2000. Declining fertility in dairy cattle: changes in traditional and endocrine patterns of fertility. Anim. Sci. 70, 487.501

Sinclair K.D., Kuran M., Gebbie F.E., Webb R., McEvoy T.G., 2000. Nitrogen metabolism and fertility in cattle: II. Development of oocytes recovered from heifers offered diets differing in their rate of nitrogen release in the rumen. J. Anim. Sci. 78, 2670-2680

Sinclair K.D., McEvoy T.G., Maxficld E.K., Maltin C.A., Young L.E., Wilmut I., Broadbent P.J., Robinson J.J., 1999. Aberrant fetal growth and development after in vitro culture of sheep zygotes. J. Reprod. Fertil. 116, 177-186

Snijders S.E.M., Dillon P., O'Callaghan D., Boland M.P., 2000. Effect of genetic merit, milk yield, body condition and lactation number on in vitro oocyte development in dairy cows. Theriogenology 53, 981-989

Symonds M.E., 1995. Pregnancy, parturition and neonatal development: interactions between nutrition and thyroid hormones. Proc. Nutr. Soc. 54, 329-343

Taylor P.M., Brameld J.M., 1999. Mechanisms and regulation of transcription and translation. In: G.E. Lobley, A. White, J.C. MacRae (Editors). Protein Metabolism and Nutrition. Proceedings of the VIIIth International Symposium on Protein Metabolism and Nutrition. Wageningen Pers, Wageningen, pp. 25-50

Thatcher W.W., Bineili M., Arnold D., Mattos R., Badinga L., Moreira F., Staples C.R., Guzeloglu A., 2001. Endocrine and physiological events from ovulation to establishment of pregnancy in cattle. In: M.G. Diskin (Editor). Fertility in the High-Producing Dairy Cow. Occasional Publication No. 26, British Society of Animal Science, Edinburgh, pp. 81-91

Webb R., Campbell B.K., Garverick H.A., Gong J.G., Gutierrez C.G., Armstrong D.G., 1999. Molecular mechanisms regulating follicular recruitment and selection. In: W.W. Thatcher, E.K. Inskeep, G.D. Niswender, C. Doberska (Editors). Reproduction in Domestic Ruminants IV. J. Reprod. Fertil., Suppl. 54, 33-48

Wilson T., Wu X-Y., Juengel J.L., Ross I.K., Lumsden J.M., Lord E.A., Dodds K.G., Walling G.A., McEwan J.C., O'Connell A.R., McNatty K.P., Montgomery G.W., 2001. Highly prolific Booroola sheep have a mutation in the intracellular kinase domain of bone morphogenetic protein $1 \mathrm{~B}$ receptor (ALK-6) that is expressed in both oocytes and granulosa cells. Biol. Reprod. 64, 1222-1235

Wrenzycki C., De Sousa P., Overstrom E.W., Duby R.T., Herrmann D., Watson A.J., Niemann H., O'Callaghan D., Boland M.P., 2000. Effects of superovulated heifer diet type and quantity on relative mRNA abundances and pyruvate metabolism in recovered embryos. J. Reprod. Fertil. $118,69.78$

Young L.E., Fernandes K., McEvoy T.G., Butterwith S.C., Gutierrez C.G., Carolan C., Broadbent P.J., Robinson J.J., Wilmut I., Sinclair K.D., 200I. Epigenetic change in $I G F 2 R$ is associated with fetal overgrowth after sheep embryo culture. Nat. Genet. 27, 153-154

Young L.E., Gutierrez C.G., Butterwith S.C., Robinson J.J., Broadbent P.J., McEvoy T.G., Wilmut I., Sinclair K.D., 1999. Altered IGF binding protein expression is associated with large offspring syndrome in fetal sheep. Theriogenology 51, 196

Young L.E., Sinclair K.D., Wilmut, 1., 1998. Large offspring syndrome in cattle and sheep. Rev. Reprod. 3, 155-163

Young V.R., Ajami A.M., 2001. Metabolism 2000: the emperor needs new clothes. Proc. Nutr. Soc. $60,27-44$ 


\section{STRESZCZENIE}

\section{Żywienie w ekspresji potencjalu rozrodczego}

W badaniach nad zagadnieniami zywieniowymi w rozrodzie przeważały dotychczas prace nad wpływem żywienia na zjawiska związane z rozrodem, takie jak: okres dojrzałości płciowej, występowanie owulacji u gatunków z monoowulacją i rzeczywistą liczbę komórek jajowych produkowanych przez samice gatunków z mnogą owulacją jak świnie i owce. Obecnie uwaga skierowana jest na badania wpływu żywienia podczas najważniejszych okresów rozwoju płodowego na późniejsze możliwości produkcyjne, włączając $w$ to rozród. Wiadomo już, że żywienie w czasie wczesnego rozwoju zarodkowego może wpływać na przebieg krzywej wzrostu płodu i masę przy urodzeniu. Są również dane wskazujące, że żywienic podczas owogenezy wpływa nie tylko na liczbę komórek jajowych, ale także na rozwój zarodka i, prawdopodobnie, na późniejszy wzrost i procesy rozwojowe płodu. W okresic, kiedy funkcjonalny genom skupia uwage żywieniowców, obserwacje te stwarzają wyjątkową i cenną możliwość prowadzenia badań wiążących zmiany produkcyjności zwierzęcia $z$ biologią molekularną i komórkową, stanowiącą podstawę tych zmian. W pracy przedstawiono wiele przykładów wpływu składników pokarmowych na ekspresję genów w czasie najważniejszych okresów rozwoju zarodkowego i płodowego. W ten sposób pokazano, że żywienie in utero ma wplyw na podniesienie produkcyjności zwierząt poprzez aktywacje genomu. 